\title{
The Impact of RMB Exchange Rate Changes on China's Export Trade to Countries and Regions along the Belt and Road
}

\author{
Pei-Zhi WANG \\ Shandong University of Finance and Economics \\ SUFE \\ Jinan, China \\ wpzmail@126.com
}

\author{
Zhe-Ning Yu; Yu-Han Zheng \\ Shandong University of Finance and Economics \\ SUFE \\ Jinan, China \\ ljxyzn@163.com
}

\begin{abstract}
Based on the panel data of 45 countries along the Belt and Road from 2010 to 2016, this paper analyzes the impact of RMB exchange rate changes on China's export trade by means of the OLS hybrid regression, panel fixed effect model and dynamic panel GMM model. And the findings show that the dynamic panel GMM model is more reasonable, which means that China's export trade to countries and regions along the Belt and Road will be affected by the previous export, and the appreciation of the RMB exchange rate and the increase in volatility will have a negative impact on China' $s$ exports to countries and regions along the Belt and Road. Moreover, both the differential GMM model and the system GMM model are adopted to analyze the three-component sample of the free trade zone, and it is found that the income level of the foreign countries is the most important factor affecting China's exports to countries and regions along the Belt and Road, the increase in income levels of low-income countries and regions such as ASEAN will make China's export trade to these countries larger than the EU and other high-income countries and regions.
\end{abstract}

Keywords-The "Belt and Road" initiative; RMB exchange rate; Export trade; Income level

\section{INTRODUCTION}

On July 21, 2005, the Central Bank announced the reform of the RMB exchange rate. Before the implementation of the RMB exchange rate reform, the nominal exchange rate of the RMB against the US dollar in 2005 was 8.19. By 2016, the nominal exchange rate of the RMB against the US dollar was 6.64. On the one hand, the appreciation of the RMB exchange rate will increase the relative price of China's export products. It reduces the competitiveness of export products in the international market, thus reducing the demand for foreign products. On the other hand, the appreciation of the RMB will not only increase the cost of production materials and labor wages of domestic enterprises, but also increase the relative price of products and ultimately affect the quantity of China's product exports.

In 2015, Xi Jinping proposed the development vision of the "Silk Road Economic Belt" and the "21st Century Maritime Silk Road". Since the "One Belt, One Road" has been put forward, China's total exports to countries and regions along the "Belt and Road" have been increasing year by year, and the total export price accounts for about $50 \%$ to $60 \%$ of China's total export price.

\section{LITERATURE REVIEW}

The impact of exchange rate changes on a country's export trade is mainly divided into two aspects: exchange rate changes and exchange rate fluctuations. In general, the impact of changes in exchange rate levels on a country's export trade is relatively simple. Foreign studies on the impact of exchange rate changes on a country's export trade, were mainly to study whether the demand price elasticity of a country's import and export commodities meets Marshall Lerner's conditions, which explains the relationship between exchange rate changes and the balance of payments. relationship. Krugman (1987) and other studies believe that Marshall Lerner's conditions are established, Rose (1991), Demirden (1995), Boyd (2001) studied that Marshall Lerner's conditions are not established.

According to the deficiencies of the existing literature, the innovations of this paper are as follows: First, the paper adds the dummy variables of the free trade zone to the model, and analyzes the "China-ASEAN Free Trade Area" and the two important regional economic integration organizations of the European Union. Second, this paper not only studies the impact of RMB exchange rate changes on China's export trade to countries along the "Belt and Road", but also studies the RMB exchange rate fluctuations. Third, this paper adds the introduction of geographical distance, an important factor affecting a country's export trade.

\section{THEORETICAL HYPOTHESIS}

\section{A. Actual bilateral exchange rate}

The actual bilateral exchange rate is an important factor affecting the trade volume of a country. Generally speaking, the appreciation of a country's currency will increase the relative price of the country's exports, reducing the competitiveness of similar products in the international market, finally promoting the country's exports.

\section{B. Actual bilateral exchange rate volatility}

At present, most of the literatures suggest that an increase of exchange rate fluctuations will promote the development of the country's export trade. Hayakawa \& Kimura (2009) believed that the increase of exchange rate fluctuations will 
have a negative impact on the country's exports. $\mathrm{Gu} \mathrm{Yu}, \mathrm{Gao}$ Tiemei (2007) found that both long-term and short-term fluctuations of the RMB exchange rate will generate an export trade to China. Therefore, this article expects that the exchange rate fluctuations will have a negative impact on China's export trade to countries and regions along the "Belt and Road".

\section{Virtual variable of free trade zone}

In general, the establishment of a free trade zone will promote a country's exports (provided that the country is a member of the free trade zone). China is a member of the "China-ASEAN Free Trade Area", but it is not a member of the European Union. Therefore, this article expects that the establishment of the "China-ASEAN Free Trade Area" will have a positive impact on China's export trade to countries and regions along the "Belt and Road", and the establishment of the EU will be an export trade to China's countries and regions along the "Belt and Road" have negative impacts.

\section{MEASUREMENT MODEL AND DATA DESCRIPTION}

\section{A. Model building \\ $\operatorname{lnex}_{\mathrm{it}}=\beta_{0}+\beta_{1} \operatorname{lne}_{\mathrm{it}}+\beta_{2} \mathrm{~V}_{\mathrm{it}}+\beta_{3} \operatorname{lny}_{\mathrm{it}}+\beta_{4} \operatorname{lndist}_{\mathrm{t}}+\beta_{5}$ asean $_{\mathrm{it}}+\beta_{6} \mathrm{eu}_{\mathrm{it}}+\mu_{\mathrm{it}}$}

Among them, ex ${ }_{i t}$ represents China's total exports to countries and regions along the "Belt and Road",e $e_{i t}$ represents the actual bilateral exchange rate between China and the countries and regions along the "Belt and Road", and $\mathrm{v}_{\text {it }}$ represents the actual bilateral between China and the countries along the "Belt and Road". Yit represents the level of income abroad, dist $t_{t}$ represents the distance between China and the countries and regions along the "Belt and Road", and $\operatorname{asean}_{\mathrm{i}}$ indicates whether it is a dummy variable of the "China-ASEAN Free Trade Area", and $\mathrm{eu}_{\mathrm{it}}$ indicates whether it is "The virtual variable of the EU. This paper introduces $\operatorname{asean}_{\mathrm{i}}$ and $\mathrm{eu}_{\mathrm{it}}$ in the model, and judges whether the establishment of the free trade zone has an impact on China's export trade to countries and regions along the "Belt and Road" by judging its coefficient and significance.

\section{B. Data source and description}

The data used in this paper is the panel data for 2010-2016 countries and regions along the "Belt and Road". Among them, the bilateral real exchange rate $\left(\mathrm{e}_{\mathrm{it}}\right)$ comes from the Bank for International Settlements, using the indirect quotation method, that is, the increase in value indicates the appreciation of the $\mathrm{RMB}$, and the decrease in value is the devaluation of the RMB. Volatility of $\mathrm{RMB}$ exchange rate $\left(\mathrm{v}_{\mathrm{it}}\right)$ refers to the practice of Zhang Bowei (2014), which is calculated based on the ratio of the spot exchange rate minus the exchange rate of the previous period and the previous exchange rate, and takes the absolute value. The actual export value of China's countries and regions along the "Belt and Road" is calculated according to the following formula:

$$
\mathrm{ex}_{\mathrm{it}}=\text { nex }_{\mathrm{it}} / \mathrm{use}_{\mathrm{it}} / \mathrm{cpic}
$$

Nex it represents the bilateral nominal export value (in US dollars) of China and the countries along the "Belt and Road", the data comes from the National Bureau of Statistics; use $e_{i t}$ is expressed as the nominal exchange rate of the US dollar against the RMB (indirect quotation method), data from the world Bank; cpic is the consumer price index for our residents $(2010=100)$, and the data comes from the World Bank.

The foreign income level $y_{i t}$ is expressed by the actual GDP of each country, and the data comes from the World Bank. The distance between China and the countries and regions along the "Belt and Road" is from the Indo.com website. The dummy variable asean $_{\text {it }}$ of the "China-ASEAN Free Trade Area" is recorded as 1 if these countries are members of the "ChinaASEAN Free Trade Area", otherwise it is recorded as 0. The EU's dummy variable $\mathrm{eu}_{\mathrm{i}}$, if these countries are members of the European Union, is recorded as 1, otherwise it is recorded as 0 . 


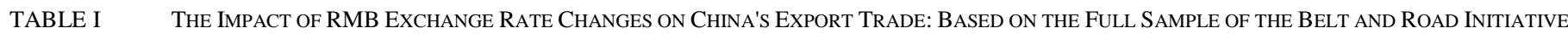

\begin{tabular}{|c|c|c|c|c|}
\hline & OLS Mixed Regression & Panel Fixing Effect & $\begin{array}{l}\text { Differential GMM } \\
\text { Regression }\end{array}$ & System GMM Regression \\
\hline Lneit & $\begin{array}{c}-0.0720 * * * \\
(0.0242)\end{array}$ & $\begin{array}{c}-0.117 * * * \\
(0.0236)\end{array}$ & $\begin{array}{c}-0.0314 * * \\
(0.0477)\end{array}$ & $\begin{array}{c}-0.0367 * * * \\
(0.0481)\end{array}$ \\
\hline Vit & $\begin{array}{l}-0.00375 \\
(0.00242)\end{array}$ & $\begin{array}{c}-0.00468 * * * \\
(0.000479)\end{array}$ & $\begin{array}{l}-0.00186^{*} \\
(0.00104)\end{array}$ & $\begin{array}{c}-0.00250 * * * \\
(0.000948)\end{array}$ \\
\hline Lnyit & $\begin{array}{l}1.013 * * * * \\
(0.0414)\end{array}$ & $\begin{array}{l}1.005 * * * \\
(0.0950)\end{array}$ & $\begin{array}{c}0.896^{* * * *} \\
(0.110)\end{array}$ & $\begin{array}{c}0.630 * * * \\
(0.181)\end{array}$ \\
\hline Lndistt & $\begin{array}{c}-0.749^{* *} \\
(0.300)\end{array}$ & & & $\begin{array}{c}-1.691 * * * \\
(0.277) \\
\end{array}$ \\
\hline Aseanit & $\begin{array}{l}0.559^{*} \\
(0.320)\end{array}$ & & & $\begin{array}{l}0.621^{* * *} \\
(1.015)\end{array}$ \\
\hline Euit & $\begin{array}{l}-0.225^{*} \\
(0.143)\end{array}$ & & & $\begin{array}{c}-0.253^{* *} \\
(0.310)\end{array}$ \\
\hline $\operatorname{Lnex(-1)}$ & & & $\begin{array}{l}0.218 * * * \\
(0.0722)\end{array}$ & $\begin{array}{c}0.450 * * * \\
(0.112)\end{array}$ \\
\hline Constant & $\begin{array}{c}-8.870 * * * \\
(2.522)\end{array}$ & $\begin{array}{c}-15.04 * * * \\
(2.420)\end{array}$ & $\begin{array}{c}-10.92 * * * * \\
(3.156)\end{array}$ & $\begin{array}{c}-7.730 * * \\
(6.920)\end{array}$ \\
\hline Number & 640 & 640 & 512 & 576 \\
\hline
\end{tabular}

From Table 1, the following conclusions can be drawn:

First, among the four regression results, the coefficient lne $_{\text {it }}$ of the RMB exchange rate level is negative, and both are statistically significant, indicating that the appreciation of the RMB exchange rate will be directed to countries and regions along the "Belt and Road" in China. The export trade has a negative impact.

Second, differential GMM and system GMM estimates, the RMB exchange rate fluctuations are significantly negative, but the coefficient is relatively small, indicating that the RMB exchange rate fluctuation will China has a negative impact on the export trade of countries and regions along the "Belt and Road", but this impact is relatively small.

Third, among the four regression results, the foreign income level lny $y_{i t}$ is significant at the $1 \%$ significance level, and the coefficient value is relatively large. For example, the OLS mixed regression results show that for every $1 \%$ increase in foreign income level, China's export trade to the country increases by $101.3 \%$, indicating that the income level of countries and regions along the "Belt and Road" is the important factors affecting China's export trade to countries and regions along the "Belt and Road". The higher the income level, the more China promotes the development of export.

Fourth, in the OLS mixed regression and systematic GMM regression results, the geographical distance lndist $_{t}$ is significantly negative, and the coefficient of the systematic GMM regression result is relatively large, that is, the geographical distance of the same country in China. For every
$1 \%$ increase, China's export trade with the country will decrease by $169.1 \%$, indicating that geographical distance is an important factor affecting China's export trade to countries along the "Belt and Road". The export trade has a great inhibitory effect.

Fifth, only in the system GMM regression results, the coefficient of the "China-ASEAN Free Trade Area" dummy variable asean ${ }_{i t}$ is significantly positive at the $5 \%$ significance level, and the coefficient is relatively high. It indicates that the establishment of the "China-ASEAN Free Trade Area" is conducive to the increase of China's export trade to ASEAN countries, and this positive impact is significant.

Sixth, only in the system GMM regression results, the EU dummy variable e $u_{i t}$ is significantly negative at the saliency level of $5 \%$, but the coefficient is relatively small, indicating that the establishment of the "China-ASEAN Free Trade Area" is for China to the EU countries. The development of oral trade has a negative impact, but this effect is not very significant.

Seventh, in the differential GMM and systematic GMM regression results, the explained variable $\operatorname{lnex}(-1)$ of the lag phase is at the $1 \%$ significance level. The following is significant, indicating that the dynamic panel GMM model will be more reasonable than the OLS hybrid regression and panel fixed effect models, that is, China's export trade to countries and regions along the "Belt and Road" will be affected by the previous export.I 
B. Grouped sample based on free trade zone

TABLE II The Impact of RMB Exchange Rate Changes on China's EXPort Trade: A Grouped SAmple Based on Free Trade Zone

\begin{tabular}{|c|c|c|c|c|c|c|}
\hline & \multicolumn{2}{|c|}{ ASEAN } & \multicolumn{2}{|c|}{$\overline{\mathrm{EU}}$} & \multicolumn{2}{|c|}{ Others } \\
\hline & $\begin{array}{c}\text { Differential } \\
\text { GMM }\end{array}$ & System GMM & $\begin{array}{c}\text { Differential } \\
\text { GMM }\end{array}$ & $\begin{array}{l}\text { System } \\
\text { GMM }\end{array}$ & $\begin{array}{c}\text { Differential } \\
\text { GMM }\end{array}$ & $\begin{array}{l}\text { System } \\
\text { GMM }\end{array}$ \\
\hline $\operatorname{Lnex}(-1)$ & $\begin{array}{c}0.0546 \\
(0.0683)\end{array}$ & $\begin{array}{l}0.0577 * \\
(0.0985)\end{array}$ & $\begin{array}{c}0.174 \\
(0.177)\end{array}$ & $\begin{array}{c}0.466^{* * *} \\
(0.116)\end{array}$ & $\begin{array}{l}0.166 * * \\
(0.0747)\end{array}$ & $\begin{array}{c}0.516 * * * \\
(0.110)\end{array}$ \\
\hline lneit & $\begin{array}{c}0.0631 \\
(0.0397)\end{array}$ & $\begin{array}{l}-0.0352 \\
(0.0447)\end{array}$ & $\begin{array}{c}-0.228 * * \\
(0.221)\end{array}$ & $\begin{array}{l}-0.135 * \\
(0.163)\end{array}$ & $\begin{array}{c}-0.00273^{*} \\
(0.111)\end{array}$ & $\begin{array}{l}0.0519 \\
(0.100)\end{array}$ \\
\hline vit & $\begin{array}{c}0.00310 * * * \\
(0.000732)\end{array}$ & $\begin{array}{c}0.00283 * * \\
(0.00114)\end{array}$ & $\begin{array}{l}-0.365 * \\
(0.189)\end{array}$ & $\begin{array}{c}-0.638 * * * \\
(0.202)\end{array}$ & $\begin{array}{c}-0.0366 \\
(0.166)\end{array}$ & $\begin{array}{l}-0.457 * \\
(0.234)\end{array}$ \\
\hline lnyit & $\begin{array}{c}1.217 * * * \\
(0.146)\end{array}$ & $\begin{array}{c}1.186 * * * \\
(0.183)\end{array}$ & $\begin{array}{c}0.829 * * * \\
(0.266)\end{array}$ & $\begin{array}{c}0.390 * * * \\
(0.108)\end{array}$ & $\begin{array}{c}0.853 * * * \\
(0.130)\end{array}$ & $\begin{array}{c}0.505 * * * \\
(0.218)\end{array}$ \\
\hline lndistt & $\begin{array}{c}-2.476 * * * \\
(0.435)\end{array}$ & $\begin{array}{c}-2.985 * * * \\
(0.940)\end{array}$ & $\begin{array}{l}-1.403 * \\
(0.789)\end{array}$ & $\begin{array}{c}-3.776 * * \\
(1.834)\end{array}$ & $\begin{array}{c}-1.509 * * * \\
(0.344)\end{array}$ & $\begin{array}{l}-2.173 * \\
(1.592)\end{array}$ \\
\hline Constant & $\begin{array}{c}-10.482 \\
(7.593)\end{array}$ & $\begin{array}{c}-4.984 * * \\
(6.966)\end{array}$ & $\begin{array}{c}-27.106^{*} \\
(3.395)\end{array}$ & $\begin{array}{c}-38.401 * * \\
(15.06)\end{array}$ & $\begin{array}{l}-19.368 \\
(3.875)\end{array}$ & $\begin{array}{l}-9.576 \\
(11.21)\end{array}$ \\
\hline Number & 80 & 90 & 208 & 234 & 224 & 252 \\
\hline
\end{tabular}

First, in the ASEAN sample, the RMB exchange rate level lne $e_{i t}$ is not statistically significant, and indicates that the change in the RMB exchange rate has no obvious effect on China's export trade to ASEAN countries, probably because it is in the "China-ASEAN Free Trade Area". On the one hand, China's trade with ASEAN countries is more in the form of RMB settlement. On the other hand, China and ASEAN countries have cut tariffs drastically. The relevant system dividends have seriously weakened the RMB exchange rate changes to ASEAN countries.

Second, according to the regression results of the threecomponent sample, the significance of the RMB exchange rate fluctuation vit is higher than the RMB exchange rate level lne $e_{i t}$, which shows that the RMB exchange rate fluctuations are generated by China's export trade to countries and regions along the "Belt and Road". The impact, and compared with the impact of the RMB exchange rate $\ln _{i t}$, the impact of RMB exchange rate fluctuations on China's export trade to countries along the "Belt and Road" is quite obvious.

Third, according to the regression results, foreign income levels $\operatorname{lny}_{\mathrm{it}}$, are statistically significant at the $1 \%$ significance level, and indicates that the foreign income level is the most important factor affecting China along the "Belt and Road". Observing the coefficient of foreign income level lny $y_{i t}$ in the three groups of regression results, the coefficient of ASEAN countries is larger than the other two groups, indicating that the increase in income of ASEAN countries is the biggest driving effect on China's exports to ASEAN countries. Second, nonASEAN and non-EU countries and regions, and the increase in income of EU countries has the least effect on China's export trade to EU countries, which may be related to the economic development level of these countries.

\section{CONCLUSIONS AND POLICY RECOMMENDATIONS}

\section{A. Conclusions}

In general: First, the appreciation of the RMB exchange rate will have a negative impact on China's exports to countries and regions along the "Belt and Road". Second, foreign income levels are the most important factors affecting China's export trade to countries along the "Belt and Road", and the increase in foreign income levels for China's exports to these countries and regions. The pulling effect is very significant. Third, the geographical distance between the two countries is also an important factor affecting China's export trade to countries and regions along the "Belt and Road". The increase in distance is very negative for China's exports to these countries and regions. Fourth, the establishment of the "China-ASEAN Free Trade Area" is conducive to stimulating China's export trade with ASEAN countries, but the establishment of the EU has a negative impact on China's exports to EU countries. This is because China is not a member of the European Union. The country does not enjoy the preferential policies and policies of EU member states.

From the perspective of the free trade zone: First, the negative impact of the appreciation of RMB on China's exports to ASEAN countries is far less than the impact of the volatility of the RMB exchange rate. This may be because the "ChinaASEAN Free Trade Area" was established. China's trade with ASEAN countries is more in the form of RMB settlement, and China and ASEAN countries have cut tariffs drastically. The relevant system dividends have seriously weakened the impact of changes in the RMB exchange rate on China's export trade to ASEAN countries. Second, The increase in the income of each country is the biggest driving effect on China's exports to ASEAN countries, followed by non-ASEAN and non-EU countries and regions, while the EU countries have the least pulling effect, indicating low-income countries such as ASEAN. The increase in the income level of the region will be 
greater for China's export trade to these countries than for countries and regions with high incomes such as the EU.

\section{B. Suggestions}

The Chinese government should pay attention to preventing the negative impact of the appreciation of the RMB on China's export trade to countries and regions along the Belt and Road. Although China implements a managed floating exchange rate system, the weight of the US dollar in a basket of currencies is very large. With the withdrawal of the US quantitative easing policy, the bilateral exchange rate of China's currency with other countries and regions other than the US dollar has risen sharply so far, which will inevitably lead to the negative impact of China's export trade to countries and regions along the Belt and Road.

In the process of continuous promotion of the "Belt and Road Initiative", we must actively develop the concept of mutual benefit and win-win cooperation, and actively sign regional economic integration agreements such as free trade zones with countries and regions along the "Belt and Road" to make full use of free trade zones and other regions. The institutional dividends released by the economic integration agreement have reduced the negative impact of RMB exchange rate changes on China's exports to countries and regions along the "Belt and Road".

With the rapid development of global economic integration, China should actively sign a "local currency swap agreement" with countries and regions along the "Belt and Road" to actively expand the regionalization of the RMB, thereby supporting bilateral relations between China and the countries along the "Belt and Road". Trade should be settled in RMB, which will minimize the negative impact of RMB exchange rate changes on China's exports to countries and regions along the "Belt and Road".

\section{REFERENCES}

[1] Barkoulas, "Exchange Rate Effects on The Volume and Variability of Trade Flows"Journal of International Money and Finance,2002,pp.418496.

[2] Dellas,H.,B.Zilberfarb."Real Exchange Rate Volatility and International Trade:A Reexamination of The Theory"Southern Economic Journal,1993,pp.641-647.

[3] Chowdhury,"R.Abdur.Does Exchange Rate Volatility Depress Trade Flows? Evidence From Error Correction Models"The Review of Economics and Statistics, 1978,pp.700-706.

[4] Bahmani-Oskooee,M.Devaluation and The J-Curve:,"Some Evidence From LDCs"The Review of Economics and Statistics, 1985,pp.500-504.

[5] Dai Xiang, Zhang Erzhen.,"Crisis Shock, Exchange Rate Fluctuation and Export Performance - - An Empirical Analysis Based on Multinational Panel Data"Financial Research,2011,pp.47-56.(In Chinese)

[6] Fan Yijun,Lu Xiaoqin.,"An Empirical Test of the Trade Effect of RMB Exchange Rate Changes on China-ASEAN"International Trade Issues,2013,pp.164-176.(In Chinese)

[7] Zhang Bowei,Tian Shuo.,"The Nonlinear Influence of Exchange Rate Fluctuation on Export Trade-Based on the Research of Country Panel Data" International Trade Issues,2014,pp.131-139.(In Chinese)

[8] Cao Wei,Zuo Yang.,"The Change of RMB Exchange Rate Level and the Impact of Exchange Rate Fluctuation on Import Trade-Based on the Research of Provincial Panel Data"International Trade Issues,2014,pp.42-52. (In Chinese)

[9] Xu Jiayun,Zhai Jiadong,Mao Qilin.,"The RMB Exchange Rate, Product Quality and Enterprise Export Behavior--An Empirical Study of Chinese Manufacturing Enterprises"Financial Research,2015,pp.1-17. (In Chinese) 